\title{
Review \\ Endocrine Disrupting Compounds Removal Methods from Wastewater in the United Kingdom: A Review
}

\author{
China K. Gadupudi 1,*, Louis Rice ${ }^{2}$, Libin Xiao ${ }^{3}$ and Komali Kantamaneni ${ }^{4}$ \\ 1 Polystar Plastics Ltd., Southampton SO14 5RB, UK; chinna_pudi@yahoo.co.uk \\ 2 Department of Architecture and the Built Environment, University of the West of England, Bristol BS16 \\ 1QY, UK; Louis.Rice@uwe.ac.uk \\ 3 International Department, University of Wales Trinity Saint David, Swansea SA1 5HF, UK; \\ Lilyxlb@126.com \\ 4 Warsash School of Maritime Science and Engineering, Solent University, Southampton SO14 OYN, UK; \\ Komali.kantamaneni@solent.ac.uk \\ * Correspondence: chinna_pudi@yahoo.co.uk
}

Received: 29 January 2019; Accepted: 19 February 2019; Published: 21 March 2019 (Version 1, doi: 10.3390/sci1010015.v1)

\begin{abstract}
Endocrine disrupting compounds (EDCs) are contaminants with estrogenic or androgenic activity that negatively impact human and animal communities. These compounds have become one of the significant concerns for wastewater treatment in recent decades. Several studies have evaluated EDC removal methods from wastewater across the globe including the United Kingdom (UK). Accordingly, the current study reviews EDC removal methods from municipal/domestic wastewater in the United Kingdom (UK) for the period of 2010-2017. The research highlights that despite the relative efficacy of existing chemical and physical methods for removing certain EDCs from wastewater there is emerging evidence supporting the need for more widespread application of nature-based and biological approaches, particularly the use of biofilms. The analysis reveals that there have been relatively few research studies on EDC removal methods have been carried out in the UK in the 2010-2017 period and none of the research focused on EDC removal using biofilms. Finally, this review suggests that more research is needed to remove EDCs, particularly through the application of biofilms, from municipal wastewater in current scenarios.
\end{abstract}

Keywords: wastewater treatment; temperatures; systematic review; biofilms; endocrine disrupting compounds

\section{Introduction}

The occurrence of endocrine disrupting compounds (EDCs) in wastewaters, aquatic systems and drinking water is considered one of the main environmental problems globally. Endocrine disrupting compounds (EDCs) have gained significant interest in recent decades in the academic press because of the many, serious diseases related to them. Exposure to EDCs is interlinked with decreased fertility, changed sexual behaviour, and amplification of abnormalities and cancers in humans and laboratory animals [1-3]. Kavlock et al. [4] defines EDC as "an exogenous agent that interferes with the synthesis, secretion, transport, binding, action, or elimination of natural hormones in the body which are responsible for the maintenance of homeostasis, reproduction, development and or behaviour". Several hundreds of chemicals may have endocrine disrupting properties [5,6]. More than 100 substances are categorised as potential endocrine disrupters such as: carbon disulfide, ophenylphenol, tetrabrominated diphenyl ether, 4-chloro-3-methylphenol, 2,4-dichlorophenol, resorcinol, 4-nitrotoluene, 2,2'-bis(4-(2,3-epoxypropoxy) phenyl) propane, 4-octylphenol, estrone (E1), $17 \alpha$-ethinylestradiol (EE2), and 17 $\beta$-estradiol ( $\beta$ E2 [7]. The main EDCs include the following 
pharmaceuticals: triclosan, nonylphenol, nonylphenol ethoxylates, octylphenol, octylphenol ethoxylates, bisphenol A, phytoestrogens, and steroid hormones have been identified in wastewater [8] and, these compounds also frequently occur in domestic wastewater, industrial wastewaters and livestock wastes [9-12]. These and other associated EDCs such as: Bisphenol A (BPA), Polychlorinated biphenyls (PCBs) and phthalates, have been identified in human serum, fat, and umbilical cord blood [13-16]. The four important categories of EDCs are: natural steroidal estrogens, synthetic estrogens, phytoestrogens, and various industrial chemicals (xenoestrogens) contaminants have a strong estrogenic strength.

Natural and synthetic estrogens have greater estrogenic effects than phyto- and xenoestrogens [17-20]. Nevertheless, the concentrations of phyto- and xenoestrogens in aquatic environments are usually higher. Recent research indicates that several sewage treatment plant effluents and rivers in the UK comprise sufficient quantities of estrogenic compounds to induce harmful effects on aquatic species [21-26]. The occurrence of EDC pollutants in wastewater creates a huge concern to humans and animals and therefore, the current paper provides an overview of the adverse effects of EDC contaminants and removal methods which were used in the UK for the period of 2010-2017. The research highlights that despite the relative efficacy of existing chemical and physical methods for removing certain EDCs from wastewater there is emerging evidence supporting the need for more widespread application of nature-based and biological approaches, particularly the use of biofilms. This review helps water and environmental engineers, biologists, chemical engineers, chemists, civil engineers, and microbiologists gain up-to-date knowledge on EDCs in wastewater and removal methods in the UK.

\section{Endocrine Disrupting Compounds and Their Impacts}

Endocrine disrupting compounds are a type of exogenous endocrine disruptors and encompass natural hormones and synthetic compounds secreted by humans and animals. The majority of EDCs have not been studied completely, analytical approaches for many of the recognised EDCs have yet to be established, and the stages of toxicological consequences or impacts are yet to be conducted. Since 1940, there has been a rapid increase in the number and usage of chemicals for various purposes and some of those chemicals have been discharged into the environment [15]. This chemical upsurge has changed the environment ecosystems and caused damage to human health and wildlife (Table 1). The first publication on EDCs came out in 1962 which emphasised that Dichloroiphenyltrichloroethane (DDT) could be accountable for the reduction of bird populations owing to reproductive failure triggered by DDT and other associated harmful chemicals. It is predicted that more than $24 \%$ of human disorders and diseases are caused by environmental factors across the globe [27]. Endocrine related disease rates have risen due to the sharp increase in use and application of manufactured chemicals. Since 1970 production of plastics has risen from 50 million to 300 million tonnes today and, the chemical industry has experienced a huge growth in global sales which has increased from $£ 126$ billion in 1970 to over $£ 2.9$ trillion in 2013 [28].

Table 1. EDC paths of exposure in humans. Source: Adapted from Gore et al. [15].

\begin{tabular}{|c|c|c|}
\hline $\begin{array}{l}\text { How Humans are Exposed to } \\
\text { EDCs }\end{array}$ & EDC Source & Examples of EDC \\
\hline $\begin{array}{l}\text { Consumption of contaminated } \\
\text { water or food }\end{array}$ & Industrial wastewater or ground water & $\begin{array}{l}\text { PCBs, dioxins, } \\
\text { compounds, DDT }\end{array}$ \\
\hline $\begin{array}{l}\text { Consumption of contaminated } \\
\text { water or food }\end{array}$ & $\begin{array}{l}\begin{array}{l}\text { Discharge of chemicals from food or } \\
\text { beverages }\end{array} \\
\end{array}$ & BPA, phthalates, chlorpyrifos, DDT \\
\hline Contact with skin or inhalation & $\begin{array}{l}\text { Household furniture treated with flame } \\
\text { retardants }\end{array}$ & Brominated flame retardant (BFR) \\
\hline $\begin{array}{l}\text { Contact with skin and/or } \\
\text { inhalation }\end{array}$ & $\begin{array}{l}\text { Pesticides used in agriculture, homes, or for } \\
\text { public disease }\end{array}$ & $\begin{array}{l}\text { DDT, chlorpyrifos, } \\
\text { pyrethroids }\end{array}$ \\
\hline Application to skin & $\begin{array}{l}\text { Vector control, certain cosmetics and } \\
\text { personal care products }\end{array}$ & $\begin{array}{l}\text { Parabens, phthalates, insect } \\
\text { repellents triclosan }\end{array}$ \\
\hline $\begin{array}{l}\text { Biological transfer from mother's } \\
\text { milk }\end{array}$ & $\begin{array}{l}\text { Maternal body burden due to past and } \\
\text { or/current exposures }\end{array}$ & $\begin{array}{l}\text { Several EDCs are found in breast } \\
\text { milk }\end{array}$ \\
\hline
\end{tabular}


Snyder (2003) [18] found that estrogenic compounds in drinking water is not responsible (highly likely) for adverse human health effects because of the relatively small amounts of estrogenic content in water compared to the quantity in foods. However, exposure to EDCs for humans is distinct from aquatic organisms such as fish, therefore, an equivalent hormonal response might not be anticipated $[29,30]$. In summary, various natural and synthetic chemical compounds have been identified that induce estrogenic responses and several studies specify that EDCs are ubiquitous in diverse media, and their probable risks to humans and lab animals are very high. Therefore, EDCs are of concern worldwide because of their wide range of negative impacts on the environment. EDCs have complex molecular structure and distinctive biological systematic mechanism and as a result cannot be effectively removed by sewage treatment plants (STPs) [31] but are effectively processed in wastewater treatment plants.

\section{Wastewater Treatments and EDCs Removal Procedures}

Several types of wastewater treatment plants (WTPs) have been proven to eliminate significant quantities of several EDCs from the wastewater. However, low concentrations of EDCs in wastewater can still lead to in-stream concentrations that are of significant quantities to harm aquatic organisms $[32,33]$. The toxic consequences of many EDCs are not fully known and require further scrutiny. The actual amount experienced by aquatic organisms is dependent upon the amount of water available for dilution in the receiving stream. Based on EDCs physicochemical characteristics, EDCs can be removed from waste water via various methods such as: absorption, adsorption, chemical degradation, biological degradation, transformation and volatilisation [34,35]. Several studies reported that elimination efficiency via wastewater treatment differs significantly depending on the kind of element and removal procedure [36-38]. Cutting-edge research specifies that endocrine active substances which are primarily found in domestic sources were more vulnerable to dissolution and removal. With other types of contaminants, very little reduction may occur through the WTP. If these harder chemicals must be eliminated, application of advanced wastewater treatment technologies may be needed $[39,40]$. Thus, the technology applied at any given plant must be based on a thorough understanding of wastewater constituents.

Table 2 specifies that some of the EDC compounds undergo substantial degradation as a result of biological treatment methods, predominantly nitrifying structures with longer SRTs. While sand filtration or microfiltration act to eliminate $17 \beta$-estradiol and/or $17 \alpha$-ethinylestradiol with significant efficiency; more advanced treatments like reverse osmosis, offer considerably greater removal rates..

Table 2. Kinds of treatment methods and removal efficiencies for selected EDCs. Source: Adapted from Birkett and Lester (2003) [34].

\begin{tabular}{ccc}
\hline Compound & Kinds of Method & Removal Efficacy \\
\hline Polychlorinated biphenyls (PCB) & Biofiltration & $90 \%$ \\
& Activated sludge & $90 \%$ \\
& Biofiltration/ activated sludge & $99 \%$ \\
\hline Nonylphenol (NP) & High loading/non-nitrifying & $37 \%$ \\
& Low loading/nitrifying & $77 \%$ \\
\hline NP1EO ** & High loading/non-nitrifying & $-3 \%$ degradation product produced \\
& Low loading/nitrifying & $31 \%$ \\
\hline NP2EO ** & High loading/non-nitrifying & $-5 \%$ produced as degradation product \\
& Low loading/nitrifying & $91 \%$ \\
\hline $17 \beta$-estradiol/17 $\alpha$ - Ethinylestradiol & Filtration-Sand/microfiltration & $70 \%$ \\
& Advanced treatment-Reverse osmosis & $95 \%$ \\
\hline Organotins & Primary effluent & $73 \%$ \\
& Secondary effluent & $90 \%$ \\
& Tertiary effluent & $98 \%$ \\
\hline
\end{tabular}

Several researchers investigated the removal of EDCs from wastewater through biological wastewater treatment procedures. Findings from research efforts across the globe such as; [10,41-50]; explored a range of removal outcomes for different kind of chemicals. However, it is important to 
note the methodological limitations with the above research. Firstly, treatment circumstances and objectives, such as SRT, temperature, $\mathrm{pH}$, nitrification, denitrification, and bio-P, are often not adequately defined by investigators. These issues can have an important influence on EDC removal rate at wastewater treatment plants. Secondly, sampling collection approach and analysis processes may impact the results significantly (Table 3) [32].

Table 3. EDCs removal methods and explanation. Adapted from Johnson and Sumpter (2001) [32].

\begin{tabular}{|c|c|}
\hline Removal Method & Explanation \\
\hline $\begin{array}{l}\text { Activated Carbon } \\
\text { Adsorption }\end{array}$ & $\begin{array}{c}\text { Activated carbon cost-effectively removes hydrophobic organic compounds. Activated carbon } \\
\text { is usually applied in one of two methods: (1) powdered activated carbon (PAC) and (2) } \\
\text { granular activated carbon (GAC). }\end{array}$ \\
\hline Ozonation & $\begin{array}{l}\text { Ozone is the dominant oxidant. Ozonation removes trace elements: however, this method will } \\
\text { not work efficiently in some circumstances. }\end{array}$ \\
\hline $\begin{array}{l}\text { Advanced Oxidation } \\
\text { Processes (AOPs) }\end{array}$ & $\begin{array}{c}\text { AOPs have strong oxidants and degrades strong organic pollutants and remove certain } \\
\text { inorganic pollutants in wastewater. }\end{array}$ \\
\hline Reverse Osmosis (RO) & $\begin{array}{l}\text { RO can remove EDCs based on compound magnitude and membrane properties. However, } \\
\text { RO is a less appropriate option for wastewater treatments for drinking and riverine waters. }\end{array}$ \\
\hline
\end{tabular}

Ternes et al. (1999) and Korner et al. (2001) [51,52] revealed that trickling filters (TF) were less effective in the removal of the estrogenic content from influent wastewater than activated sludge, as evidenced from two waste water treatment plants in the U.S. However, in activated sludge procedures, hydraulic residence time (HRT) and SRT are particularly significant factors in EDC removal process. In European activated sludge systems, the HRT is between four and fourteen hours [32] and this method provided better results than trickling filters. Several scientists have noticed that EDC removal with increased SRT is more efficient [42,53-57]. While microfiltration membranes on their own would not support an efficient removal of EDC, it was proposed that EDC adsorption of particulate matter, that is preserved by the membrane, would condense EDC intensity in the effluent. Other researchers [58-61] revealed that EDC removal was mainly due to biodegradation or membrane biofilms. Usually, biological procedures are the most cost effective in removal of organic EDS from wastewater, however when these organics are contaminated or non-biodegradable, physical and chemical techniques must be implemented [62-65]. These removal approaches comprise adsorption, chemical oxidation, and membrane processes. Research on advanced EDC removal procedures is being studied across the world. The following approaches are examples of innovative and traditional technologies that are appropriate for full-scale application if ultra-low EDC concentration limits are required.

\section{Methodology}

Recently published literature on EDCs and wastewater treatment allows the examination of trends in EDCs removal methods from wastewater subjects, particularly with more advanced and innovative solutions in recent years. Literature searches also help to examine the current developments in a particular research field and assist in recognising research gaps and new challenges. Current research articles about the EDCs and their effects on human and animals and EDC removal methods from the UK wastewater were reviewed. Accordingly, Sciencedirect.com, a research article search engine has been used to evaluate the research articles which were published between 2000-2017 on EDC removal from municipal/domestic wastewater in the United Kingdom. Therefore, suitable keywords such as: EDC and impacts, EDC in wastewater and EDC removal from municipal wastewater in the UK were searched for using Sciencedirect.com; narrowing the searching period for the 2000-2017 years for critical analysis. Subsequently, the current review analysed original research articles, book chapters, conference papers, abstracts, editorial notes, short communication and other associated documents. Almost 250 original research articles, 52 review articles, 43 short communications, and 11 technical reports were examined. A total of 47 published articles, which covered EDC removal methods from wastewaters/municipal waters were reviewed rigorously. From those, a total of 25 published articles, which covered EDC removal methods from 
UK wastewaters were reviewed rigorously. Subsequent analysis established the number of different methods for EDC removal in the UK for the period of 2010-2017. The current review also evaluated how many studies directly addressed EDC removal from wastewater treatments through the use of biofilms.

\section{Results and Discussion}

Significant research results obtained through the analysis of diverse types of published articles were scrutinised via the ScienceDirect.com database. There were a very limited number of original research articles (24) published for the period of 2010-2017 on EDC removal methods from wastewater in the UK. Only four papers addressed the removal of specific endocrine disrupting compounds from UK municipal wastewater and none of the studies addressed EDC removal by using direct biofilms. Below are the two main papers which have been published in the UK for the period of 2010-2017 which are now examined in more detail.

\subsection{Research Article-1}

This research examined the role of polyamide- 6 for the removal and recovery of the estrogenic endocrine disruptors estrone, 17 $\beta$-estradiol, $17 \alpha$-ethinylestradiol and the oxidation product 2hydroxyestradiol in water. Tizaoui et al. (2017) [66] described the removal of endocrine disrupting compounds such as estrone (E1), $17 \beta$-estradiol (E2) and $17 \alpha$-ethinylestradiol (EE2) and the oxidation product 2-hydroxyestradiol (2OHE2) from secondary treated wastewater in Wales (United Kingdom) using polyamide 6 as a sorbent material in their study. Results explored that PA6 is an effective sorbent material for the removal and recovery of EDCs from different water environments. Hydrogen bonding is the main tool compelling the adsorption of these EDCs on PA6 at pHs lesser than the EDCs pKas ( 10.5) (Figure 1) and their adsorption was not disturbed by the water matrix. In addition, PA6 was also an efficient solid phase extraction sorbent.

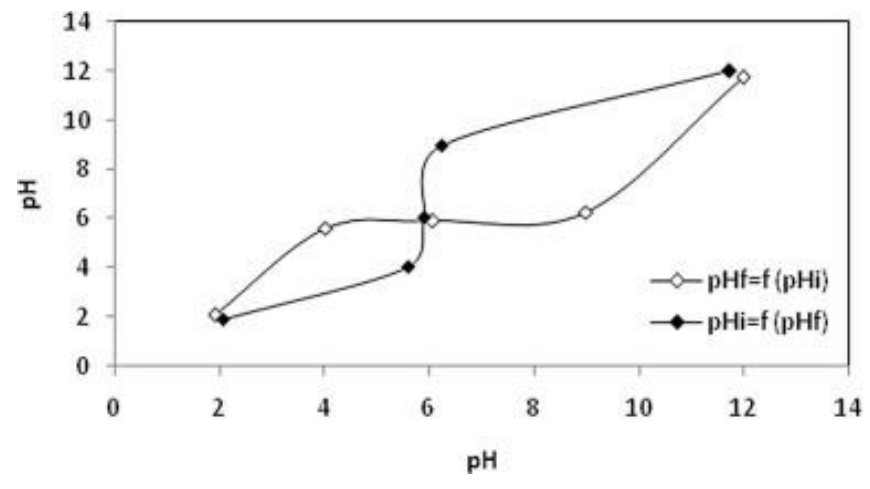

Figure 1. Correlation of the PH to the point of 0 charge of PA6.

\subsection{Research Article-2}

The This research examined the effectiveness of anaerobic digestion in removing estrogens and nonylphenol ethoxylates. Paterakis et al. (2011) [67] investigated the two groups of endocrine disrupting compounds such as steroid estrogens and nonylphenol ethoxylates, appraised under mesophilic and thermophilic circumstances during the anaerobic digestion of primary and mixed sewage sludge (Table 4) where digestion occurred more than six retention times. The research is based on the treatment of sludges in United Kingdom wastewater treatments plants. Results explored sludge intensities of both groups and proved that temporal variants and concentrations in mixed sludge are impacted by the occurrence of waste activated sludge. The biodegradation of steroid estrogens is more than $50 \%$ during initial sludge digestion. It is evident that anaerobic digestion diminishes the intensity of these compounds. This study also highlighted that anaerobic digestion 
shields the reuse environment from steroid estrogens and Nonylphenol Ethoxylates (NPEO'S) and that eliminations of NPEOs are greater in the absorption of mixed sludge.

Table 4. Sludge features, operational circumstances and digester enactment at mesophilic and thermophilic temperatures at six retention spells. Adapted from Paterakis et al. (2011) [67].

\begin{tabular}{|c|c|c|c|c|}
\hline & \multicolumn{2}{|c|}{ Mesophilic } & \multicolumn{2}{|c|}{ Thermophilic } \\
\hline & $\begin{array}{l}\text { Initial } \\
\text { Sludge }\end{array}$ & $\begin{array}{l}\text { Mixed } \\
\text { Sludge } \\
\end{array}$ & $\begin{array}{l}\text { Initial } \\
\text { Sludge }\end{array}$ & $\begin{array}{l}\text { Mixed } \\
\text { Sludge } \\
\end{array}$ \\
\hline \multicolumn{5}{|l|}{ Influent Sludges } \\
\hline VS $\left(\mathrm{g} \mathrm{L}^{-1}\right)$ & $36.5 \pm 2.6$ & $44.0 \pm 3.0$ & $29.2 \pm 0.1$ & $38.1 \pm 0.1$ \\
\hline VFA (mg acetic acid L $\left.{ }^{-1}\right)$ & $1314 \pm 68$ & $1592 \pm 44$ & $1168 \pm 98$ & $1470 \pm 52$ \\
\hline Estrone (E1) $\left(\mu \mathrm{g} \mathrm{kg}^{-1} \mathrm{dw}\right)$ & $158 \pm 14$ & $90 \pm 21$ & $64.3 \pm 2.5$ & $32.3 \pm 2$ \\
\hline $17 \beta$-Estradiol (E2) & $9 \pm 1$ & $6 \pm 1$ & $6 \pm 3$ & $3 \pm 2$ \\
\hline Estriol (E3) & $9 \pm 1$ & $8 \pm 1$ & $6 \pm 1.5$ & $5 \pm 1$ \\
\hline Estrone-3-sulfate (E1-3S) & $7.6 \pm 1.5$ & $7 \pm 1.5$ & $4 \pm 1$ & $4 \pm 1$ \\
\hline $17 \alpha$-Ethinyl estradiol (EE2) & $18 \pm 4$ & $10 \pm 2$ & $9 \pm 1$ & $10 \pm 2$ \\
\hline 4-Nonylphenol (NP) $\left(\mathrm{mg} \mathrm{kg}^{-1} \mathrm{dw}\right)$ & $0.3 \pm 0.1$ & $0.23 \pm 0.1$ & $0.23 \pm 0.1$ & $0.1 \pm 0.1$ \\
\hline Nonylphenoxy acetic acids $\left(\mathrm{NP}_{1-3} \mathrm{EC}\right)\left(\mathrm{mg} \mathrm{kg}^{-1} \mathrm{dw}\right)$ & $26.5 \pm 0.1$ & $241.5 \pm 0.1$ & $0.1 \pm 0.1$ & $0.08 \pm 0.1$ \\
\hline $\begin{array}{l}\text { Nonylphenol monoethoxylate and diethoxylate }\left(\mathrm{NP}_{1-2} \mathrm{EO}\right)\left(\mathrm{mg} \mathrm{kg}^{-1}\right. \\
\qquad \mathrm{dw})\end{array}$ & $2.1 \pm 0.5$ & $1.7 \pm 0.5$ & $15 \pm 0.1$ & $90 \pm 0.1$ \\
\hline Nonylphenol polyethoxylates $\left(\mathrm{NP}_{3-12} \mathrm{EO}\right)\left(\mathrm{mg} \mathrm{kg}^{-1} \mathrm{dw}\right)$ & $1.5 \pm 0.4$ & $0.7 \pm 0.4$ & $1.3 \pm 0.25$ & $0.7 \pm 0.25$ \\
\hline \multicolumn{5}{|l|}{$\begin{array}{c}\text { Operating Circumstances } \\
\end{array}$} \\
\hline$T\left({ }^{\circ} \mathrm{C}\right)$ & $35 \pm 0.2$ & $35 \pm 0.2$ & $55 \pm 0.2$ & $55 \pm 0.2$ \\
\hline SRT $(\mathrm{d})$ & 30 & 30 & 15 & 15 \\
\hline $\operatorname{OLR}\left(\mathrm{kg} \mathrm{VS} \mathrm{m}^{-3} \mathrm{~d}^{-1}\right)$ & $1.3 \pm 0.1$ & $1.5 \pm 0.1$ & $1.9 \pm 0.0$ & $2.5 \pm 0.0$ \\
\hline $\mathrm{TS}\left(\mathrm{g} \mathrm{L}^{-1}\right)$ & $26.7 \pm 2.3$ & $38.5 \pm 1.3$ & $22.7 \pm 1.8$ & $33.9 \pm 1.3$ \\
\hline VS $\left(\mathrm{g} \mathrm{L}^{-1}\right)$ & $19.5 \pm 1.6$ & $23.9 \pm 2.0$ & $11.5 \pm 4.5$ & $22.0 \pm 2.2$ \\
\hline $\mathrm{pH}$ & $7.1 \pm 0.1$ & $7.5 \pm 0.1$ & $7.2 \pm 0.0$ & $7.6 \pm 0.1$ \\
\hline $\mathrm{ORP}(\mathrm{mV})$ & $-320.8 \pm 12.8$ & $-380.6 \pm 29.8$ & $-411.6 \pm 36.9$ & $-419.0 \pm 34.9$ \\
\hline VFA (mg acetic acid L-1) & $176.4 \pm 7.3$ & $132.9 \pm 17.3$ & $1098.5 \pm 189.6$ & $829.3 \pm 145.9$ \\
\hline Total alkalinity $\left(\mathrm{mg} \mathrm{L}^{-1}\right)$ & $2399 \pm 37$ & $5362 \pm 63$ & $4000 \pm 453$ & $4770 \pm 85$ \\
\hline \multicolumn{5}{|l|}{ Biogas } \\
\hline Daily production $\left(\mathrm{l} \mathrm{d}^{-1}\right)$ & $0.8 \pm 0.0$ & $0.8 \pm 0.1$ & $1.0 \pm 0.1$ & $1.6 \pm 0.1$ \\
\hline $\operatorname{GRP}\left(\mathrm{m}^{3} \mathrm{~m}^{-3} \mathrm{~d}^{-1}\right)$ & $0.51 \pm 0.0$ & $0.52 \pm 0.0$ & $0.67 \pm 0.0$ & $1.08 \pm 0.0$ \\
\hline SGP $\left(\mathrm{m}^{3} \mathrm{CH}_{4} \mathrm{~kg}^{-1} \mathrm{VS}_{\text {removed }}\right)$ & $0.7 \pm 0.1$ & $0.6 \pm 0.1$ & $0.4 \pm 0.1$ & $0.7 \pm 0.1$ \\
\hline Biogas yield $\left(\mathrm{m}^{3} \mathrm{~kg}^{-1} \mathrm{VS}_{\text {removed }}\right)$ & $0.95 \pm 0.2$ & $0.80 \pm 0.1$ & $0.60 \pm 0.1$ & $1.02 \pm 0.1$ \\
\hline \multicolumn{5}{|l|}{ Elimination efficiencies (\%) } \\
\hline VS & $53.5 \pm 6.9$ & $40.1 \pm 2.1$ & $43.2 \pm 3.0$ & $32.4 \pm 1.0$ \\
\hline TS & $47.3 \pm 8.5$ & $33.7 \pm 4.6$ & $37.0 \pm 4.4$ & $29.8 \pm 2.6$ \\
\hline $\mathrm{g} \mathrm{VS}_{\text {removed }} \mathrm{d}^{-1}$ & $1.07 \pm 0.1$ & $0.98 \pm 0.1$ & $2.24 \pm 0.2$ & $1.84 \pm 0.1$ \\
\hline
\end{tabular}

These are the main two papers written by various researchers on the removal of EDC compounds in wastewater in the UK. Furthermore, several articles addressed EDCs but not in relation to the removal of UK wastewater.

\section{Conclusions}

The current review presents endocrine disrupters removal methods which were established for the period of 2010-2017 from wastewater in the United Kingdom. Accordingly, the current study analysed original research articles (250), review articles (52), short communication (43) and other associated documents via the ScienceDirect.com database. A total of 25 published articles, which covered EDC removal methods from UK wastewaters were reviewed rigorously. From those articles, two key research articles have been discussed in more depth. Analysis results explored that research on EDCs removal methods in the UK is extremely sparse and existing research addressed only limited endocrine disrupters such as bisphenol A and 4-tert-octylphenol. Most of the existing research evaluated physical and chemical methods rather than biological methods. Several published articles that explored the removal rate efficiency (70-90\%) of EDCs by using chemical and physical methods are good but concluded that biofilms might be the better opportunity. Some other researchers identified that some advanced treatments such as Advanced Oxidation Processes (AOPs), Reverse Osmosis (RO) and Activated Carbon Adsorption (ACA) are better methods for the removal of EDCs from wastewater however they are expensive. Finally, this research concluded that very limited 
research had been undertaken on EDCs removal from wastewater in the UK and more research is needed in the near future.

Author Contributions: C.K.G., L.R. and K.K. designed the study and the methodology. C.K.G. and L.R. wrote the paper; K.K., L.R. and L.X. modified the manuscript.

Funding: This research received no external funding.

Conflicts of Interest: The authors declare no conflict of interest

\section{References}

1. Pelch, K.E.; Beeman, J.M.; Niebruegge, B.A.; Winkeler, S.R.; Nagel, S.C. Endocrine-disrupting chemicals (EDCs) in mammals. In Hormones and Reproduction of Vertebrates; Elsevier: Amsterdam, The Netherlands, 2011; pp. 329-371.

2. Vandenberg, L.N. Low-dose effects of hormones and endocrine disruptors. In Vitamins $\mathcal{E}$ Hormones; Elsevier: Amsterdam, The Netherlands, 2014; Volume 94, pp. 129-165.

3. Patisaul, H.B. Endocrine disruption by dietary phyto-oestrogens: Impact on dimorphic sexual systems and behaviours. Proc. Nutr. Soc. 2017, 76, 130-144.

4. Kavlock, R.J.; Daston, G.P.; DeRosa, C.; Fenner-Crisp, P.; Gray, L.E.; Kaattari, S.; Lucier, G.; Luster, M.; Mac, M.J.; Maczka, C. Research needs for the risk assessment of health and environmental effects of endocrine disruptors: A report of the US EPA-sponsored workshop. Environ. Health Perspect. 1996, 104, 715-740.

5. Diamanti-Kandarakis, E.; Bourguignon, J.-P.; Giudice, L.C.; Hauser, R.; Prins, G.S.; Soto, A.M.; Zoeller, R.T.; Gore, A.C. Endocrine-disrupting chemicals: An Endocrine Society scientific statement. Endocr. Rev. 2009, 30, 293-342.

6. Bergman, Å.; Heindel, J.J.; Jobling, S.; Kidd, K.; Zoeller, T.R.; Organization, W.H. State of the Science of Endocrine Disrupting Chemicals 2012; World Health Organization: Geneva, Switzerland, 2013.

7. European Commission. European Workshop on the Impact of Endocrine Disrupters on Human Health and the Environment. Environment and Climate Research Programme, DG XII, 1997; EUR 17549; European Commission: Brussels, Belgium, 1997.

8. Omar, T.F.T.; Ahmad, A.; Aris, A.Z.; Yusoff, F.M. Endocrine disrupting compounds (EDCs) in environmental matrices: Review of analytical strategies for pharmaceuticals, estrogenic hormones, and alkylphenol compounds. TrAC Trends Anal. Chem. 2016, 85, 241-259.

9. Sin, J.-C.; Lam, S.-M.; Mohamed, A.R.; Lee, K.-T. Degrading Endocrine Disrupting Chemicals from Wastewater by $\mathrm{TiO}_{2}$ Photocatalysis: A Review. Int. J. Photoenergy 2012, 2012, doi:10.1155/2012/185159.

10. Becker, D.; Rodriguez-Mozaz, S.; Insa, S.; Schoevaart, R.; Barceló, D.; De Cazes, M.; Belleville, M.P.; Sanchez-Marcano, J.; Misovic, A.; Oehlmann, J.; et al. Removal of endocrine disrupting chemicals in wastewater by enzymatic treatment with fungal laccases. Org. Process Res. Dev. 2017, 21, 480-491.

11. Wee, S.Y.; Aris, A.Z. Endocrine disrupting compounds in drinking water supply system and human health risk implication. Environ. Int. 2017, 106, 207-233.

12. Grześkowiak, T.; Czarczyńska-Goślińska, B.; Zgoła-Grześkowiak, A. Biodegradation of Selected Endocrine Disrupting Compounds. In Toxicity and Biodegradation Testing; Springer: Berlin, Germany, 2018; pp. 1-27.

13. Balabanič, D.; Rupnik, M.; Klemenčič, A.K. Negative impact of endocrine-disrupting compounds on human reproductive health. Reprod. Fertil. Dev. 2011, 23, 403-416.

14. Louis, G.M.B.; Sundaram, R.; Sweeney, A.M.; Schisterman, E.F.; Maisog, J.; Kannan, K. Urinary bisphenol A, phthalates, and couple fecundity: The Longitudinal Investigation of Fertility and the Environment (LIFE) Study. Fertil. Steril. 2014, 101, 1359-1366.

15. Gore, A.C.; Crews, D.; Doan, L.L.; La Merrill, M.; Patisaul, H.; Zota, A. Introduction to Endocrine Disrupting Chemicals (EDCs); A Guide for Public Interest Organizations and Policy-Makers; Endocrine Society: Washington, DC, USA, 2014

16. Treviño, L.S.; Katz, T.A. Endocrine disruptors and developmental origins of nonalcoholic fatty liver disease. Endocrinology 2017, 159, 20-31.

17. Servos, M.R. Review of the aquatic toxicity, estrogenic responses and bioaccumulation of alkylphenols and alkylphenol polyethoxylates. Water Qual. Res. J. 1999, 34, 123-178.

18. Snyder, S.A.; Westerhoff, P.; Yoon, Y.; Sedlak, D.L. Pharmaceuticals, personal care products, and endocrine disruptors in water: Implications for the water industry. Environ. Eng. Sci. 2003, 20, 449-469. 
19. Meng, Z.; Chen, W.; Mulchandani, A. Removal of estrogenic pollutants from contaminated water using molecularly imprinted polymers. Environ. Sci. Technol. 2005, 39, 8958-8962.

20. LaFleur, A.D.; Schug, K.A. A review of separation methods for the determination of estrogens and plasticsderived estrogen mimics from aqueous systems. Anal. Chim. Acta 2011, 696, 6-26.

21. Purdom, C.; Hardiman, P.; Bye, V.; Eno, N.; Tyler, C.; Sumpter, J. Estrogenic effects of effluents from sewage treatment works. Chem. Ecol. 1994, 8, 275-285.

22. Harries, J.E.; Janbakhsh, A.; Jobling, S.; Matthiessen, P.; Sumpter, J.P.; Tyler, C.R. Estrogenic potency of effluent from two sewage treatment works in the United Kingdom. Environ. Toxicol. Chem. 1999, 18, 932937.

23. Harries, J.E.; Sheahan, D.A.; Matthiessen, P.; Neall, P.; Rycroft, R.; Tylor, T.; Jobling, S.; Routledge, E.J.; Sumpter, J.P. A survey of estrogenic activity in United Kingdom inland waters. Environ. Toxicol. Chem. 1996, 15, 1993-2002.

24. Rodgers-Gray, T.P.; Jobling, S.; Morris, S.; Kelly, C.; Kirby, S.; Janbakhsh, A.; Harries, J.E.; Waldock, M.J.; Sumpter, J.P.; Tyler, C.R. Long-term temporal changes in the estrogenic composition of treated sewage effluent and its biological effects on fish. Environ. Sci. Technol. 2000, 34, 1521-1528.

25. Thomas, K.V.; Hurst, M.R.; Matthiessen, P.; Waldock, M.J. Characterization of estrogenic compounds in water samples collected from United Kingdom estuaries. Environ. Toxicol. Chem. Int. J. 2001, 20, 2165-2170.

26. Peck, M.; Gibson, R.W.; Kortenkamp, A.; Hill, E.M. Sediments are major sinks of steroidal estrogens in two United Kingdom rivers. Environ. Toxicol. Chem. Int. J. 2004, 23, 945-952.

27. Fingerhut, M.A.; Nelson, D.I.; Driscoll, T.; Concha-Barrientos, M.A.; Steenland, K.Y.; Punnett, L.A.; PrüssUstün, A.; Leigh, J.; Corvalan, C.; Eijkemans, G.; et al. The contribution of occupational risks to the global burden of disease: Summary and next steps. Med. Lav. 2006, 97, 313-321.

28. Kemf, E. GCO-Global Chemicals Outlook: Towards Sound Management of Chemicals; United Nations Environment Programme: Nairobi, Kenya, 2013.

29. Geyer, H.J.; Rimkus, G.G.; Scheunert, I.; Kaune, A.; Schramm, K.-W.; Kettrup, A.; Zeeman, M.; Muir, D.C.; Hansen, L.G.; Mackay, D. Bioaccumulation and occurrence of endocrine-disrupting chemicals (EDCs), persistent organic pollutants (POPs), and other organic compounds in fish and other organisms including humans. In Bioaccumulation-New Aspects and Developments; Springer: Berlin, Germany, 2000; pp. 1-166.

30. Scruggs, C.; Hunter, G.; Snyder, E.; Long, B.; Snyder, S. EDCs in wastewater: what's the next step? Water Environ. Technol. 2005, 17, 24-31.

31. Lee, Y.; Escher, B.I.; Von Gunten, U. Efficient removal of estrogenic activity during oxidative treatment of waters containing steroid estrogens. Environ. Sci. Technol. 2008, 42, 6333-6339.

32. Johnson, A.C.; Sumpter, J.P. Removal of endocrine-disrupting chemicals in activated sludge treatment works. Environ. Sci. Technol. 2001, 35, 4697-4703.

33. Sumpter, J.P.; Johnson, A.C. 10th Anniversary perspective: Reflections on endocrine disruption in the aquatic environment: From known knowns to unknown unknowns (and many things in between). J. Environ. Monit. 2008, 10, 1476-1485.

34. Birkett, J. Endocrine Disrupters in Wastewater and Sludge Treatment Processes; CRC: Boston, MA, USA, 2003; pp. 35-58.

35. Liu, Z.-H.; Kanjo, Y.; Mizutani, S. Removal mechanisms for endocrine disrupting compounds (EDCs) in wastewater treatment-Physical means, biodegradation, and chemical advanced oxidation: A review. Sci. Total Environ. 2009, 407, 731-748.

36. Brown, P.; Gill, S.; Allen, S. Metal removal from wastewater using peat. Water Res. 2000, 34, 3907-3916.

37. Chen, G. Electrochemical technologies in wastewater treatment. Sep. Purif. Technol. 2004, 38, 11-41.

38. Pérez, S.; Barceló, D. Fate and occurrence of X-ray contrast media in the environment. Anal. Bioanal. Chem. 2007, 387, 1235-1246.

39. Cheremisinoff, N.P. Handbook of Water and Wastewater Treatment Technologies; Butterworth-Heinemann: Oxford, UK, 2001.

40. McCann, B. Disruptive influences. Water 2004, 21, 20-22.

41. Lee, H.-B.; Peart, T.E.; Gris, G.; Chan, J. Endocrine-disrupting chemicals in industrial wastewater samples in Toronto, Ontario. Water Qual. Res. J. 2002, 37, 459-472.

42. Andersen, L.; Kinnberg, K.; Holbech, H.; Korsgaard, B.; Bjerregaard, P. Evaluation of a 40 day assay for testing endocrine disrupters: Effects of an anti-estrogen and an aromatase inhibitor on sex ratio and vitellogenin concentrations in juvenile zebrafish (Danio rerio). Fish Physiol. Biochem. 2004, 30, 257-266. 
43. Giger, W.; Gabriel, F.L.; Jonkers, N.; Wettstein, F.E.; Kohler, H.-P.E. Environmental fate of phenolic endocrine disruptors: Field and laboratory studies. Philos. Trans. R. Soc. A Math. Phys. Eng. Sci. 2009, 367, 3941-3963.

44. Lee, H.-B.; Peart, T.E.; Svoboda, M.L. Determination of endocrine-disrupting phenols, acidic pharmaceuticals, and personal-care products in sewage by solid-phase extraction and gas chromatography-mass spectrometry. J. Chromatogr. A 2005, 1094, 122-129.

45. Drewes, J.E.; Hemming, J.; Ladenburger, S.J.; Schauer, J.; Sonzogni, W. An assessment of endocrine disrupting activity changes during wastewater treatment through the use of bioassays and chemical measurements. Water Environ. Res. 2005, 77, 12-23.

46. Auriol, M.; Filali-Meknassi, Y.; Tyagi, R.D.; Adams, C.D.; Surampalli, R.Y. Endocrine disrupting compounds removal from wastewater, a new challenge. Process Biochem. 2006, 41, 525-539.

47. Chang, H.-S.; Choo, K.-H.; Lee, B.; Choi, S.-J. The methods of identification, analysis, and removal of endocrine disrupting compounds (EDCs) in water. J. Hazard. Mater. 2009, 172, 1-12.

48. Esplugas, S.; Bila, D.M.; Krause, L.G.T.; Dezotti, M. Ozonation and advanced oxidation technologies to remove endocrine disrupting chemicals (EDCs) and pharmaceuticals and personal care products (PPCPs) in water effluents. J. Hazard. Mater. 2007, 149, 631-642.

49. Rosal, R.; Rodríguez, A.; Perdigón-Melón, J.A.; Petre, A.; García-Calvo, E.; Gómez, M.J.; Agüera, A.; Fernández-Alba, A.R. Occurrence of emerging pollutants in urban wastewater and their removal through biological treatment followed by ozonation. Water Res. 2010, 44, 578-588.

50. Yu, Y.; Wu, L.; Chang, A.C. Seasonal variation of endocrine disrupting compounds, pharmaceuticals and personal care products in wastewater treatment plants. Sci. Total Environ. 2013, 442, 310-316.

51. Körner, W.; Spengler, P.; Bolz, U.; Schuller, W.; Hanf, V.; Metzger, J.W. Substances with estrogenic activity in effluents of sewage treatment plants in southwestern Germany. 2. Biological analysis. Environ. Toxicol. Chem. 2001, 20, 2142-2151.

52. Ternes, T.A.; Stumpf, M.; Mueller, J.; Haberer, K.; Wilken, R.-D.; Servos, M. Behavior and occurrence of estrogens in municipal sewage treatment plants-I. Investigations in Germany, Canada and Brazil. Sci. Total Environ. 1999, 225, 81-90.

53. Koh, Y.; Chiu, T.; Boobis, A.; Cartmell, E.; Scrimshaw, M.; Lester, J. Treatment and removal strategies for estrogens from wastewater. Environ. Technol. 2008, 29, 245-267.

54. Ziels, R.M.; Lust, M.J.; Gough, H.L.; Strand, S.E.; Stensel, H.D. Influence of bioselector processes on $17 \alpha-$ ethinylestradiol biodegradation in activated sludge wastewater treatment systems. Environ. Sci. Technol. 2014, 48, 6160-6167.

55. Ekama, G.A. Recent developments in biological nutrient removal. Water SA 2015, 41, 515-524.

56. Amin, M.M.; Bina, B.; Ebrahim, K.; Yavari, Z.; Mohammadi, F. Biodegradation of natural and synthetic estrogens in moving bed bioreactor. Chin. J. Chem. Eng. 2018, 26, 393-399.

57. Raghavan, D.S.S.; Qiu, G.; Ting, Y.-P. Fate and removal of selected antibiotics in an osmotic membrane bioreactor. Chem. Eng. J. 2018, 334, 198-205.

58. Ivashechkin, P.; Corvini, P.; Fahrbach, M.; Hollender, J.; Konietzko, M.; Meesters, R.; Schröder, H.F.; Dohmann, M. Comparison of the elimination of endocrine disrupters in conventional wastewater treatment plants and membrane bioreactors. In 2nd IWA Leading-Edge on Water and Wastewater Treatment Technologies; IWA Publishing: London, UK, 2005; p. 211.

59. Khanal, S.K.; Xie, B.; Thompson, M.L.; Sung, S.; Ong, S.-K.; Van Leeuwen, J. Fate, transport, and biodegradation of natural estrogens in the environment and engineered systems. Environ. Sci. Technol. 2006, 40, 6537-6546.

60. Holloway, R.W.; Regnery, J.; Nghiem, L.D.; Cath, T.Y. Removal of trace organic chemicals and performance of a novel hybrid ultrafiltration-osmotic membrane bioreactor. Environ. Sci. Technol. 2014, 48, 10859-10868.

61. Sahar, E.; Ernst, M.; Godehardt, M.; Hein, A.; Herr, J.; Kazner, C.; Melin, T.; Cikurel, H.; Aharoni, A.; Messalem, R. Comparison of two treatments for the removal of selected organic micropollutants and bulk organic matter: Conventional activated sludge followed by ultrafiltration versus membrane bioreactorE. Sahar et al. Removal of organic micropollutants and bulk organic matter: Comparison of CAS-UF and MBR. Water Sci. Technol. 2011, 63, 733-740.

62. Basha, C.A.; Chithra, E.; Sripriyalakshmi, N. Electro-degradation and biological oxidation of nonbiodegradable organic contaminants. Chem. Eng. J. 2009, 149, 25-34. 
63. Carmen, Z; Daniela, S. Textile organic dyes-characteristics, polluting effects and separation/elimination procedures from industrial effluents-a critical overview. In Organic Pollutants Ten Years after the Stockholm Convention-Environmental and Analytical Update; IntechOpen: Rijeka, Croatia, 2012.

64. Blanco, J.; Torrades, F.; De la Varga, M.; García-Montaño, J. Fenton and biological-Fenton coupled processes for textile wastewater treatment and reuse. Desalination 2012, 286, 394-399.

65. Von Sperling, M.; de Lemos Chernicharo, C.A. Biological Wastewater Treatment in Warm Climate Regions; IWA Publishing: London, UK, 2005; Volume 1.

66. Tizaoui, C.; Fredj, S.B.; Monser, L. Polyamide-6 for the removal and recovery of the estrogenic endocrine disruptors estrone, $17 \beta$-estradiol, $17 \alpha$-ethinylestradiol and the oxidation product 2-hydroxyestradiol in water. Chem. Eng. J. 2017, 328, 98-105.

67. Paterakis, N.; Chiu, T.; Koh, Y.; Lester, J.; McAdam, E.; Scrimshaw, M.; Soares, A.; Cartmell, E. The effectiveness of anaerobic digestion in removing estrogens and nonylphenol ethoxylates. J. Hazard. Mater. 2012, 199, 88-95.

(C) 2019 by the authors. Submitted for possible open access publication under the terms and conditions of the Creative Commons Attribution (CC BY) license (http://creativecommons.org/licenses/by/4.0/). 